\title{
Gospodarka odpadami Termiczne przekształcanie odpadów - spalarnie i współspalarnie
}

\author{
Maciej Siekierski, Karolina Majewska, \\ Sławomir Podsiadło
}

\section{STRESZCZENIE}

Gospodarka odpadami jest szeregiem procesów związanych z wytwarzaniem, zbieraniem i nadzorem odpadów, z czego kluczową rolę pełni ich przetwarzanie. Obejmuje także zagadnienia związane z postępowaniem z miejscami ich unieszkodliwienia. Obecnie, jest to jedno z najważniejszych zagadnień dotyczących współczesnej cywilizacji w związku z narastającym problemem zanieczyszczenia środowiska. Artykuł jest kolejnym z serii artykułów poświęconych gospodarce odpadami [Wieczorek, Siekierski 2020]. Celem artykułu jest przekazanie obiektywnych informacji dotyczących termicznego przekształcania odpadów, wokół którego narosło szereg mitów dotyczacych zarówno jego zalet, jak i szkodliwości dla środowiska. Jest to szczególna metoda przetwarzania odpadów, bo może polegać zarówno na ich unieszkodliwianiu, jak i odzysku. Termiczne przekształcanie odpadów odbywa się przede wszystkim w spalarniach, jak również we współspalarniach, którymi mogą być oprócz specjalnie zaprojektowanych do tego celu instalacji dedykowanych, czyli takich, których jedynym przedmiotem działania jest termiczne przekształcanie odpadów np. poprzez ich spalanie, także i takie instalacje przemysłowe, które już wcześniej zainstalowane zostały w zakładach przemysłowych o zupełnie innym profilu, np. w cementowniach, elektrowniach i elektrociepłowniach. W jednym z kolejnych z cyklu artykułów zostana również przedstawione należące do tej samej grupy procesów termicznych metody utylizacji odpadów z wykorzystaniem technologii plazmowych. Interesujące porównanie tych trzech technologii można znaleźć w pracy opublikowanej w 2018 r. w czasopiśmie Rynek Energii [Rajca, Zajemska 2018].

Nie jest zamiarem autorów lobbowanie za jakąkolwiek metodą termicznego przekształcania odpadów.

Słowa kluczowe: termiczne przekształcanie odpadów, spalarnie, współspalarnie, odpady, gospodarka odpadami, gospodarowanie odpadami

\section{Gospodarka odpadami}

Podstawowym aktem prawa dotyczącym odpadów oraz gospodarki odpadami jest ustawa o odpadach (uod).

Odpady, to „każda substancja lub przedmiot, których posiadacz pozbywa się, zamierza się pozbyć lub do których pozbycia się jest obowiązany" [art. 3 ust. 1 pkt 6 uod].

Gospodarka odpadami, to:

- wytwarzanie odpadów,

- gospodarowanie odpadami [art. 3 ust. 1 pkt 3 uod]. 
Gospodarowanie odpadami, to zbieranie, transport i przetwarzanie odpadów, postępowanie $\mathrm{z}$ miejscami ich unieszkodliwiania oraz działania związane ze sprzedawaniem i pośrednictwem w obrocie odpadami [art. 3 ust. 1 pkt 2 uod].

Przetwarzanie odpadów - „procesy odzysku lub unieszkodliwiania, w tym przygotowanie poprzedzające odzysk lub unieszkodliwianie" [art. 3 ust. 1 pkt 21 uod].

Odzysk, to z kolei „jakikolwiek proces, którego głównym wynikiem jest to, aby odpady służyły użytecznemu zastosowaniu przez zastapienie innych materiałów, które w przeciwnym przypadku zostałyby użyte do spełnienia danej funkcji, lub w wyniku którego odpady sa przygotowywane do spełnienia takiej funkcji w danym zakładzie lub ogólnie w gospodarce" [art. 3 ust. 1 pkt 14 uod].

Unieszkodliwianie odpadów, to „proces niebędący odzyskiem, nawet jeżeli wtórnym skutkiem takiego procesu jest odzysk substancji lub energii" [art. 3 ust. 1 pkt 30 uod].

Proces, który może polegać zarówno na unieszkodliwianiu odpadów, jak i ich odzysku, to termiczne przekształcanie odpadów.

\section{Termiczne przekształcanie odpadów}

Termiczne przekształcanie odpadów, to:

- spalanie odpadów przez ich utlenianie,

- inne procesy termicznego przekształcania, np.: piroliza, zgazowanie i proces plazmowy [art. 3 ust. 1 pkt 29 uod].

Termiczne przekształcanie odpadów niebezpiecznych oraz stałych odpadów komunalnych stanowi proces unieszkodliwiania [art. 158 ust. 1 uod]. Termiczne przekształcanie, w celu odzysku energii odpadów opakowaniowych, odpadów innych niż niebezpieczne, stałych odpadów komunalnych oraz odpadów roślinnych stanowi proces odzysku [art. 158 ust. 2 uod].

„Część energii odzyskanej z termicznego przekształcania odpadów zawierających frakcje biodegradowalne może stanowić energię z odnawialnego źródła energii, jeżeli są spełnione warunki techniczne zakwalifikowania części energii odzyskanej z termicznego przekształcenia odpadów jako energii z odnawialnego źródła energii" [art. 159 ust. 1 uod].

Termiczne przekształcanie odpadów poprzez ich spalenie odbywa się zgodnie z określeniami użytymi w ustawie o spalarniach odpadów lub współspalarniach odpadów [art. 155 uod]. Z technicznego punktu widzenia jedynie spalarnie od padów stanowią zazwyczaj osobne i wyspecjalizowane instalacje, położone często w pobliżu lub w obrębie aglomeracji miejskich zasilających je odpadami i wykorzystujących wytwarzaną w nich energię elektryczna (tu jednak lokalizacja instalacji ma znaczenie drugorzędne), a przede wszystkim znacznie trudniejszą $\mathrm{w}$ dalszym przesyle energię cieplną. Z własnościowego punktu widzenia sa one zwykle związane, czy to z jednostkami samorządu terytorialnego, czy też z komercyjnymi podmiotami świadczacymi usługi z zakresu gospodarki odpadowej na danym terenie. Zupełnie inaczej ma się sytuacja z systemami współspalania, które zazwyczaj oparte 
są o takie niezależne od przedsiębiorstw gospodarki odpadowej - i często wcześniej już istniejące - instalacje przemysłowe jak bloki elektrowni węglowych, elektrociepłowni, czy też piece przeznaczone do wytwarzania cementu. Trudno jest więc tu $\mathrm{z}$ technicznego punktu widzenia mówić o specjalistycznych współspalarniach odpadów.

Spalanie odpadów poza instalacjami lub urządzeniami przeznaczonymi do tego celu należy do wyjątków, wymaga szeregu zezwoleń i dotyczy np. pozostałości roślinnych [art. 31 uod].

Spalarnia odpadów, to „zakład lub jego czesść przeznaczone do termicznego przekształcania odpadów z odzyskiem lub bez odzysku wytwarzanej energii cieplnej, obejmujące instalacje i urządzenia służące do prowadzenia procesu termicznego przekształcania odpadów wraz z oczyszczaniem gazów odlotowych i wprowadzaniem ich do powietrza, kontrola, sterowaniem i monitorowaniem procesów oraz instalacjami związanymi z przyjmowaniem, wstępnym przetwarzaniem i magazynowaniem odpadów dostarczonych do termicznego przekształcania oraz instalacjami związanymi z magazynowaniem i przetwarzaniem substancji otrzymanych w wyniku spalania i oczyszczania gazów odlotowych; jeżeli współspalanie odpadów odbywa się w taki sposób, że głównym celem tej instalacji nie jest wytwarzanie energii ani wytwarzanie produktów materialnych, tylko termiczne przekształcenie odpadów, wówczas instalacja ta uważana jest za spalarnię odpadów" [art. 3 ust. 1 pkt 26 uod].

Współspalarnia odpadów, to „zakład lub jego część, których głównym przedmiotem działalności jest wytwarzanie energii lub produktów, w których wraz z paliwami sa przekształcane termicznie odpady w celu odzyskania zawartej w nich energii lub w celu ich unieszkodliwiania, obejmujące instalacje i urządzenia służące do prowadzenia procesu termicznego przekształcania wraz z oczyszczaniem gazów odlotowych i wprowadzaniem ich do atmosfery, kontrola, sterowaniem i monitorowaniem procesów, instalacjami związanymi z przyjmowaniem, wstępnym przetwarzaniem i magazynowaniem odpadów dostarczonych do termicznego przekształcania oraz instalacjami związanymi z magazynowaniem i przetwarzaniem substancji otrzymanych w wyniku spalania i oczyszczania gazów odlotowych" [art. 3 ust. 1 pkt 31 uod].

Ustawa o odpadach stawia szereg wymagań spalarniom i współspalarniom:

- „sa projektowane, budowane, wyposażane i użytkowane w sposób zapewniający osiągnięcie poziomu termicznego przekształcania odpadów, przy którym ilość i szkodliwość dla życia, zdrowia ludzi lub dla środowiska, odpadów i innych emisji powstajacych wskutek termicznego przekształcania odpadów będzie jak najmniejsza" [art. 157 ust. 1 uod],

- zarządzający są obowiązani do podejmowania niezbędnych środków ostrożności mających na celu zapobieżenie lub ograniczenie negatywnych skutków dla środowiska, w szczególności w odniesieniu do zanieczyszczeń powietrza, gleby, wód powierzchniowych i gruntowych oraz zapachów i hałasu, a także bezpośredniego zagrożenia życia lub zdrowia ludzi" [art. 160 ust. 1 uod], 
- $\quad$ wojewódzki inspektor ochrony środowiska w sytuacji zagrożenia dla życia i zdrowia ludzi lub dla środowiska, może wydać decyzję o wstrzymaniu termicznego przekształcania odpadów danej spalarni lub współspalarni [art. 161 ust. 1 uod].

Spalarnie w przytłaczającej większość są (sytuacja ta nie jest jednakże tak ściśle zdefiniowana prawnie, gdy chodzi o współspalarnie odpadów):

- inwestycjami celu publicznego, w rozumieniu ustawy o planowaniu i zagospodarowaniu przestrzennym (upzp),

- przedsięwzięciami mogącymi zawsze znacząco oddziaływać na środowisko, w rozumieniu rozporządzenia w sprawie przedsięwzięć mogących znacząco oddziaływać na środowisko, wydanego na podstawie ustawy o udostępnianiu informacji o środowisku i jego ochronie, udziale społeczeństwa w ochronie środowiska oraz o ocenach oddziaływania na środowisko (uiś),

- $\quad$ obiektami budowlanymi w rozumieniu ustawy Prawo budowlane $(\mathrm{uPb})$.

Realizacja takich obiektów wymaga uzyskania decyzji o pozwoleniu na budowę, poprzedzonej wydaniem decyzji o środowiskowych uwarunkowaniach [art. 71 ust. 1 pkt $1 \mathrm{i}$ art. 72 ust. 1 pkt 1 uiś].

Wybór sposobów zagospodarowania odpadów komunalnych [art. 3 ust. 1 pkt 7 uod] jest przedmiotem sporów pomiędzy specjalistami. W Skandynawii jeszcze w XX w. zbudowano system ciepłowni spalających odpady, pozwalający zutylizować wszystkie własne palne śmieci. W konsekwencji zmian w gospodarce odpadowej, jakie pojawiły się tam w ciagu następnych dwudziestu lat, czyli przy rosnącym recyklingu krajowym i malejącej ilości odpadów doprowadziło to do sytuacji, w której sprowadzane sa one z zagranicy. W podobnym czasie wokół Paryża zbudowano kilkanaście ciepłowni, które zagospodarowują wszystkie stałe odpady komunalne aglomeracji. Oczywiście odpady muszą być wcześniej segregowane w celu oddzielenia składników do recyklingu: metali, szkła, użytecznych $\mathrm{w}$ tej mierze tworzyw sztucznych, papieru etc. Nakazy legislacyjne próbowały wymusić odzysk i ponowne wykorzystanie zdecydowanej większości odpadów. Jednak jakość tych odpadów najczęściej nie odpowiada wymaganiom producentów mogących je przetwarzać na nowe produkty, np. z makulatury z odpadów komunalnych wytworzenie dobrej jakości papieru jest praktycznie niemożliwe. Podobnie jest też ze zmieszanymi frakcjami - metali, tworzyw sztucznych czy też w mniejszym stopniu nawet i szkła. Obecnie przy segregacji odpadów komunalnych - ręcznie, jak to się dzieje w krajach mniej rozwiniętych czy też coraz to bardziej automatycznie do czego dąży przemysł odpadowy krajów wysoko rozwiniętych - metale i szkło są oddzielane i kierowane do przeróbki hutniczej. Z kolei tworzywa sztuczne, choć w głównej swej masie nie nadają się do bezpośredniego wykorzystania w produkcji wysokiej jakości wyrobów użytkowych, sạ w coraz to większym i wymuszanym normami administracyjno-prawnymi stopniu poddawane procesowi regranulacji i powtórnego wykorzystania [Stelmach 2019].

W Polsce w 2017 r. wytworzono ok. 12 mln ton odpadów komunalnych, a ich głównymi składnikami były - w procentach wagowych, w zaokragleniu [GUS 2018]:

- tzw. odpady biodegradowalne (mieszaniny organicznych odpadów bytowych) - 30\% 
- zmieszane odpady opakowaniowe - $20 \%$

- tworzywa sztuczne $-10 \%$

- papier i tektura $-8 \%$

- $\quad$ szkło $-12 \%$

- inne (w tym materiały palne) $-20 \%$.

Tak więc, znacznie ponad $70 \%$ odpadów komunalnych - co dotyczy nie tylko Polski, stanowią substancje palne. Z tych powodów większość odpadów w krajach rozwiniętych, spalana jest albo w specjalnie do tego celu zaprojektowanych spalarniach (instalacje dedykowane), bądź też wykorzystywana w instalacjach zdolnych do ich współspalania.

\section{Spalarnie odpadów}

Obecnie funkcjonuje w Polsce osiem typowych spalarni odpadów komunalnych powiązanych z dużymi organizmami miejskimi (Białystok, Bydgoszcz, Konin, Kraków, Poznań, Rzeszów, Szczecin, Warszawa), a trzy kolejne znajdują się na różnych etapach procesu inwestycyjnego (rozbudowa spalarni ZUSOK Warszawa, Gdańsk i Olsztyn). Na chwilę obecna te osiem instalacji dedykowanych dysponuje mocami przerobowymi na poziomie 1150 tys. ton odpadów rocznie. Realnie są one odbiorcami około 1 mln ton odpadów komunalnych w skali roku. Dziewiąta z funkcjonujących instalacji (Fortum Zabrze) ma inny charakter techniczny, gdyż ogranicza się jedynie do wykorzystania wyselekcjonowanej w osobnym procesie technologicznym frakcji RDF w istniejącej już wcześniej elektrociepłowni miejskiej. Podobna inwestycja realizowana jest także w Warszawie na terenie EC Siekierki. Wszystkie wspomniane wyżej i już realizowane inwestycje powinny zwiększyć krajowy potencjał termicznego przekształcania odpadów o kolejne ok. 500 tys. ton, z czego prawie 350 tys. dotyczy dwóch inwestycji zlokalizowanych w stolicy. Bardziej szczegółowe omówienie tej problematyki zestawione zarówno z perspektywy Unii Europejskiej [Namiecińska, Wielgosiński 2016], jak i naszego kraju [Czerwińska, Wielgosiński 2019] można znaleźć w publikacjach pochodzących ze związanego z Politechniką Łódzką zespołu naukowego kierowanego przez dra hab. inż. Grzegorza Wielgosińskiego.

\section{RDF - paliwo z odpadów}

Z technicznego punktu widzenia palna frakcja odpadów komunalnych stanowi jeden z rodzajów paliwa alternatywnego zwanego też niekonwencjonalnym. Jest ona zazwyczaj określana skrótem RDF pochodzacym od angielskiej nazwy Refuse Derived Fuel (paliwo pochodzące $z$ odpadów). Warto tu zaznaczyć, że odpady komunalne są jedynie jednym z możliwych źródeł RDF, gdyż może być również produkowany z odpadów przemysłowych lub pochodzących z innej działalności komercyjnej. Głównym składnikiem municypalnego RDF są nierecyklowalne tworzywa sztuczne - z wyłączeniem poli(chlorku winylu) 
i innych polimerów zawierających fluorowce, a także papier, karton, naklejki itp. Są one wydzielane z ogólnej masy odpadów za pomocą wieloetapowego procesu technologicznego wykorzystującego m.in. takie techniki jak separacja powietrzna, balistyczna i magnetyczna. Stosowane sa także techniki posługujące się obrazowaniem podczerwonym oraz inne metody pozwalające na oddzielenie ze strumienia odpadów wtrąceń takich jak metale nieżelazne, szkło, czy też kamienie.

W końcowym etapie przetwarzania wstępnego odpady sa granulowane, co bywa określane także jako pelletowanie, tak by stanowiły homogeniczne paliwo o określonych parametrach jakościowych. Stosowane są tu zarówno metody sortowania 'pozytywnego' prowadzące do selekcji materiałów przydatnych do spalania, jak i 'negatywnego' służące wydzieleniu z przetwarzanego strumienia materiałów niepodlegających procesom utylizacji termicznej. W konsekwencji działania komitetu technicznego CEN/TC 343 problematyka związana z wykorzystaniem RDF określanego także jako SRF (Solid Recovered Fuels) została ujęta łącznie w 31 dokumentach normatywnych. I tak na przykład według regulacji EN-15359:2010 paliwa RDF sa podzielone na pięć klas jakościowych w zależności od swojej wartości opałowej wynoszącej odpowiednio powyżej $25 \mathrm{MJ} / \mathrm{kg}$ dla klasy 1 i powyżej $3 \mathrm{MJ} / \mathrm{kg}$ dla klasy 5. Dodatkowymi, istotnymi tak $\mathrm{z}$ technologicznego, jak i środowiskowego punktu widzenia parametrami dodatkowymi są także zawartość chloru niemogąca w zależności od klasy paliwa przekraczać odpowiednio od 0,2 do $3 \%$ suchej masy paliwa oraz maksymalna zawartość rtęci wynosząca od 0,02 do 0,16 mg/MJ. I tak przykładowo z punktu widzenia przemysłu cementowego możliwe do zastosowania jest jedynie paliwo zwierające nie więcej niż 0,75\% chloru w suchej masie, co organiczna zainteresowanie nim wyłącznie do klas jakościowych 1, 2 i częściowo 3. Z kolei normy EN 15591:2007 (wraz z jej późniejszą modyfikacją EN 15440:2011) odnoszą się do kwestii oznaczania zawartości biomasy w paliwach RDF. Kwestia ta, choć nie wpływa bezpośrednio na techniczna przydatność paliw tego typu staje się istotna, gdy przychodzi do określenia wielkości śladu węglowego związanego ze spalaniem paliwa o konkretnym składzie. Warto tu dodatkowo nadmienić, że zaproponowana $\mathrm{w}$ normie metoda oparta o radiochemiczny pomiar aktywności zawartego w paliwie izotopu ${ }^{14} \mathrm{C}$ (analogiczny do stosowanego $\mathrm{w}$ archeologii datowania radiowęglowego) pozwala jedynie na określenie masowego udziału frakcji biogenicznej, a nie parametru dużo bardziej realistycznego, czyli związanego z jej spaleniem efektu cieplnego.

Dla wspomnianego już wcześniej przemysłu cementowego obowiązują z kolei wytyczne Dyrektywy PE 2000/76/EC z 4.12.2000 dotyczącej spalania odpadów regulujące w sposób ścisły dopuszczalne emisje środowiskowe pochodzace z procesu spalania odpadów. Warto tu także przypomnieć, że oprócz wspomnianych powyżej zastosowań oraz rosnącego zainteresowania przemysłu energetycznego, realizującego zarówno spalanie, jak i współspalanie RDF, odpady tego typu moga być także wykorzystane w procesach pirolizy i zgazowania plazmowego. Koncentrując się jednak na głównym przedmiocie artykułu jakim jest termiczne przekształcenie odpadów należy zauważyć, że oprócz instalacji korzystających z wyselekcjonowanej wcześniej frakcji RDF popularnym rozwiązaniem są też konstrukcje dedykowane umożliwiające bezpośrednie spalanie zmieszanych, lecz nie sortowanych 
odpadów komunalnych w specjalnych przeznaczonych do tego celu paleniskach. Jako osobną klasę rozwiązań opisuje się także małe instalacje o budowie modułowej charakteryzujące się krótkim czasem montażu i rozruchu oraz możliwością stopniowego zwiększania ich możliwości przetwórczych. Ze względu na zmienny i nie do końca określony skład przetwarzanego strumienia odpadów obie te ostatnie klasy procesów są potencjalnie obciążone ryzykiem emisji środowiskowej takich substancji niebezpiecznych jak dioksyny (będące pochodną zawartości w odpadach związków chloru lub innych fluorowców), furany (będące produktem niepełnego spalania niektórych tworzyw sztucznych) oraz rtęć metaliczna i jej lotne związki. Kolejnym problemem środowiskowym są emisje 'kwaśne', w skład których wchodzą zarówno tlenki azotu, jak i tlenki siarki.

\section{Współspalarnie odpadów - cementownie, elektrownie i elektrociepłownie}

Całkowita liczba obiektów budowlanych związanych z termicznym przekształcaniem odpadów w Polsce jest, ze względu na znaczy udział współspalania odpadów, trudna do jednoznacznego określenia. Oprócz opisanych powyżej ośmiu funkcjonujących na chwilę obecną spalarni odpadów komunalnych oraz trzech kolejnych zakładów tego typu znajdujących się na różnych etapach procesu inwestycyjnego, a także jednej komunalnej współspalarni znaczącą rolę w przetwarzaniu odpadów w ten sposób realizują m.in. cementownie. W zakładach tych proces spalania odpadów ma charakter uboczny i stanowi dla nich nie tylko dodatkowe źródło wykorzystywanego w procesie produkcyjnym ciepła, ale także i źródło zysku. Pomimo zainteresowania ograniczonego do frakcji odpadów o kaloryczności 18-20 MJ/kg (czyli znacznie powyżej wprowadzonej w 2016 granicy prawnej zakazującej składowania odpadów o kaloryczności większej niż $6 \mathrm{MJ} / \mathrm{kg}$ ) czyniącego procesy współspalania zyskownymi ekonomicznie wskutek wprowadzonego wspomnianego zakazu przemysł cementowy odszedł od praktyki płacenia za spalane odpady. Co więcej, korzystając z quasi-monopolistycznej pozycji w tym sektorze usług rozpoczął on pobieranie od dostawców odpadów, stanowiących dodatkowe źródło przychodów, opłat za ich utylizację w wysokości około 200 PLN/tonę. Pomimo to, właśnie ze względu na wymogi prawne, przemysł cementowy jest obecnie odpowiedzialny za utylizację około 1,2 mln ton odpadów energetycznych w skali roku, co stanowi wartość wyższą (zarówno masowo, jak i też w znacznie większym stopniu energetycznie) od $1 \mathrm{mln}$ ton jakie co rok przetwarzaja przeznaczone do tego instalacje termicznego przekształcania odpadów. Sumując zdolności przetwórcze instalacji dedykowanych oraz cementowni, a także biorąc pod uwagę to, że w Polsce w skali roku powstaje od 5 do 6 mln ton odpadów, tego typu deficyt dotyczący zdolności przetwórczych w tym obszarze można oszacować na około $3 \mathrm{mln}$ ton/ rok, a więc na więcej niż na chwilę obecną przetwarzają łącznie instalacje dedykowane, jak też i cementownie. Kolejnym odbiorca pochodzącego ze spalania odpadów ciepła może być przemysł energetyczny. Zarówno energetyka zawodowa (przykładem może tu być należąca do PGE Elektrownia w Bełchatowie), jak też i kogeneracyjna (przykładem może tu być wspomniana już wcześniej, należąca do firmy 
Fortum, zlokalizowana w Zabrzu elektrociepłownia miejska) są zainteresowane współspalaniem odpadów komunalnych jako jednym ze środków prowadzących do celu jakim jest wielopaliowe podejście do tzw. transformacji energetycznej. Szczegóły dotyczące potencjału jaki niesie ze sobą inkorporowanie paliw alternatywnych do miksu energetycznego Polski zostały przedstawione w pochodzącym z lipca 2020 r. raporcie Instytutu Jagiellońskiego Paliwa i motory wzrostu gospodarczego. Wpływ cen surowców i produkcji energii na Polskę [Gacki, Lachowicz, Moskwik 2020]. Z kolei samorządy miejskie dysponujące z jednej strony odpada$\mathrm{mi}$, a z drugiej instalacjami energetycznymi powinny, według tego samego raportu, zamiast kupowania węgla (lub gazu) pomyśleć o takim dostosowaniu posiadanych mocy wytwórczych do obecnie oczekiwanych standardów emisyjnych, by możliwa była w nich realizacja znanej m.in. ze Skandynawii zasady moje odpady - moje ciepło.

\section{Perspektywy administracyjno-prawne instalacji dedykowanych}

Z drugiej jednak strony rozpatrywana jest także i rozbudowa potencjału instalacji dedykowanych. Przykładowo, wskutek dokonanej w 2019 r. rządowej rewizji listy takich instalacji dopuszczonych do realizacji zawiera ona obecnie około 100 wpisów (w porównaniu z 34 sprzed tejże rewizji) dotyczących instalacji potencjalnych. Niestety, spalanie odpadów niebędące w świetle prawodawstwa tak UE, jak i Polski, uznawane za proces ich recyklingu stoi, przynajmniej formalnie, w kontrze do realizacji celów ustawowych dotyczących oczekiwanego poziomu recyklingu odpadów. W konsekwencji projekty takie moga nie tylko nie znaleźć finansowania ze strumienia środków europejskich, ale w najgorszym razie, o ile zostaną sfinansowane w inny sposób i finalnie uruchomione, przyczynić się do nałożenia na eksploatujące je samorządy wysokich kar finansowych wynikających z niedotrzymania wymogów legislacyjnych w tej mierze.

Wysokość tych kar może w wielu sytuacjach znacznie przekraczać poziom oczekiwanych korzyści wynikających z realizacji takich inwestycji. Dodatkowo należy tu podkreślić, że w świetle nowej legislacji UE jaką jest Rozporządzenie Parlamentu Europejskiego i Rady (UE) 2020 / 852 z 18 czerwca 2020 r. w sprawie ustanowienia ram ułatwiających zrównoważone inwestycje dotychczas obowiązujące w tej mierze Rozporządzenie (UE) 2019/2088 nabiera kształtu zdecydowanie niekorzystnego dla samej idei spalania odpadów (Art. 13 pkt 1.). Według nowej regulacji nakazuje wprost by w ramach dążenia do przejścia na gospodarkę o obiegu zamkniętym (GOZ) działalność gospodarcza o jakimkolwiek charakterze była prowadzona w sposób, który minimalizuje spalanie odpadów i prowadzi do uniknięcia unieszkodliwiania odpadów, w tym składowania, zgodnie z zasadami hierarchii postępowania z odpadami.

W Ministerstwie Klimatu, a później Ministerstwie Klimatu i Środowiska toczyły się prace analityczne dotyczace stanu gospodarki odpadowej w Polsce. Według komunikatu samego Ministerstwa ich zakończenie w przedmiotowym obszarze tematycznym planowane było na 31.12.2020 r., a więc w chwili ukazania się w druku niniejszego artykułu finalna wersja listy 
planowanych w tym obszarze inwestycji powinna być już dostępna. Warto jest także nadmienić, że pomimo negatywnego wydźwięku wspomnianych powyżej regulacji unijnych pozytywne sygnały dotyczące współfinansowania tego typu inwestycji płyną również ze strony Narodowego Funduszu Ochrony Środowiska i Gospodarki Wodnej. Rezygnację z termicznego przekształcania odpadów postrzega on z jednej strony jako zgodę na konieczność ich składowania, z drugiej z kolei użyte w rozporządzeniu UE określenie 'minimalizacja' traktuje jako wskazówkę by procesy termiczne dotyczyły wyłącznie odpadów, których recykling nie jest możliwy lub nie jest uzasadniony ekonomicznie, a nie dążenie do całkowitej eliminacji procesów tego typu z gospodarki odpadowej. Niezależnie od prowadzonych prac zarówno przedstawiciele organizacji branżowych zajmujacych się przetwarzaniem odpadów, jak też i osoby wypowiadające się w imieniu przedsiębiorstw energetyki zawodowej będących potencjalnymi odbiorcami RDF wskazuja, że na przeszkodzie w jego szerszym wykorzystaniu jako źródła energii nie stoją ani problemy techniczne, ani organizacyjne, a jedynie brak odpowiednio korzystnych i stabilnych uregulowań prawnych w tej mierze. Dylematy dotyczace tej problematyki pojawiają się już na poziomie klasyfikacyjnym. I tak przykładowo o ile Ramowa Dyrektywa Odpadowa 2008/98/EC przewiduje możliwość utraty przez odpady statusu odpadów (end-of-waste status) to wattpliwe są zarówno kwestie ekonomiczne, jak i formalno-prawne operacji prowadzacej do dopuszczenia frakcji RDF jako produktu. Według najnowszych informacji w ciagu najbliższych kilku miesięcy dojdzie do przynajmniej częściowej harmonizacji prawa krajowego z postanowieniami cytowanej dyrektywy, co umożliwi znacznie szersze wykorzystanie RDF jako paliwa. Stanowić to będzie równocześnie moment, kiedy przepisy obowiązujące w tej mierze w Polsce staną się zbliżone do uregulowań istniejących od lat w wielu przodujących technologicznie krajach świata, takich jak USA i Kanada [Wieczorek, Siekierski 2021].

Podsumowując powyższe rozważania można bez wątpienia sformułować następujące wnioski:

- $\quad$ istniejących na chwilę obecną instalacji termicznego przekształcania odpadów jest zbyt mało,

- część z nich wymaga niewątpliwie przekształceń - rozbudowy, zmiany technologii,

- wymaga to stabilizacji prawa i to w perspektywie czasowej zdecydowanie dłuższej niż rok 2023, w którym przywoływane rozporządzenie ma być opatrzone w przepisy wykonawcze,

- panuje powszechna zgoda, co do tego, że są one niezbędne,

- próby ustalenia ich lokalizacji prowadzą jednak często do konfliktów społecznych.

\section{Piroliza odpadów}

Jak wspomniano wyżej podejście oparte na spalaniu odpadów jest obecnie kwestionowane ze względu na fakt, iż cały węgiel zawarty w materiałach stanowiących odpad komunalny trafia po spaleniu do atmosfery w postaci dwutlenku węgla. Preferowany model 
gospodarki w obiegu zamkniętym (GOZ) oraz konieczność zmniejszenia emisji $\mathrm{CO}_{2}$ powoduja, iż rosnące znaczenie zyskuje stosunkowo nowy sposób zagospodarowania odpadów, $\mathrm{w}$ tym i komunalnych, mianowicie piroliza. Jest to proces polegający na ogrzewaniu materiałów zawierających związki węgla do temperatury $500-1100^{\circ} \mathrm{C} \mathrm{w}$ zamkniętych reaktorach bez dostępu powietrza.

$\mathrm{W}$ takich warunkach substancje organiczne ulegają rozkładowi termicznemu, w którym powstaja:

- gaz złożony z lotnych węglowodorów i tlenku węgla CO (spalany w wiecznym płomieniu lub zużywany na miejscu do ogrzewania reaktora do pirolizy) - stanowi ok. 30\% wagowych produktu,

- olej popirolityczny (pirolityczny), który może być stosowany jako paliwo opałowe lub jako olej napędowy - stanowiący ok. 30\% wagowych produktu,

- sadza popirolityczna, stosowana z różnym powodzeniem w dziedzinach, gdzie stosuje się sadze czyste, dotąd otrzymywane w procesach petrochemicznych - ok. $40 \%$ wagowych produktu.

Podane tu udziały frakcji w produktach pirolizy mają wyłącznie orientacyjny charakter, gdyż są one silnie zależne od: składu odpadu poddawanego pirolizie, budowy pieca do pirolizy oraz reżimu temperaturowego procesu. Każdy z trzech wymienionych produktów pirolizy ma wartość użytkowa, a skierowanie sadzy do procesów wytwórczych może istotnie zmniejszyć ilość $\mathrm{CO}_{2}$ emitowanego do atmosfery o ok. 40\%, w porównaniu ze spaleniem całej wyjściowej ilości odpadu.

W całej masie odpadów komunalnych tworzywa sztuczne są materiałami dającymi się najłatwiej sklasyfikować - w porównaniu z nieprzewidywalnymi składami innych odpadów bytowych. Z tego powodu piroliza odpadowych tworzyw sztucznych jest przodującym obszarem w zagospodarowaniu odpadów komunalnych tym sposobem. Należy jednak dodać, że metody pirolityczne są dopiero na początkowym etapie zastosowań przemysłowych.

Recykling odpadów z tworzyw sztucznych stanowi poważny, nierozwiązany do dziś problem w skali globalnej. Ogromna 'wyspa' plastikowych śmieci o powierzchni około $1 \mathrm{mln} \mathrm{km²}$, pływająca po Pacyfiku, jest na to ewidentnym dowodem. Tylko w kilku najlepiej zorganizowanych państwach funkcjonuje jedyny skuteczny sposób na eliminację wyrzucania przez konsumentów plastikowych odpadów. W Niemczech oraz Skandynawii za opakowania z tworzyw sztucznych płaci się kaucje przy zakupie towarów. Opróżnione opakowania klienci zwracaja do sklepów otrzymując zwrot pieniędzy, ale nawet tam, część tych odpadów jest zanieczyszczona resztkami produktów w nich sprzedawanych. Niewielka część odpadów z tworzyw sztucznych (główną frakcję stanowi tu poli(tereftalan etylenu) - PET wykorzystywany w produkcji butelek do napojów) możliwa jest do zawrócenia do ponownego wykorzystania w wytwarzaniu tego samego wyrobu o nieobniżonej jakości. Główna ich masa, i tak niestety dzieje się np. w przypadku regranulacji poliolefin wykorzystywanych w przemyśle opakowań spożywczych, możliwa jest jednak do użycia jedynie przy produkcji wyrobów niższej i pogarszającej się systematycznie za każdym kolejnym 
obrotem koła recyklingu, aż do całkowitej utraty funkcji użytkowych, jakości. Funkcjonalne przetwarzanie takich materiałów, zwłaszcza tych stanowiących bazę coraz to bardziej popularnych opakowań wielowarstwowych, jest również coraz to bardziej technologicznie skomplikowane. Co, pamiętając o coraz to większych przeszkodach formalnych, jakie pojawiaja się przy pozyskiwaniu energii przez ich spalanie czyni ich pirolizę coraz to bardziej atrakcyjnym i obiecujacym procesem przemysłowym.

Odpady tworzyw sztucznych można sklasyfikować w kilku grupach:

- PET,

- poliolefiny (polietylen, polipropylen),

- PCV - polichlorek winylu (i inne materiały zawierające chlor),

- odpady gumowe (materiały zawierające siarkę),

- polimery i kopolimery zawierające styren (polistyren, ABS, SAN).

Pomijając całkowitą techniczną nieopłacalność spalania i pirolizy dobrze recyklowalnego PET oraz opisane w dalszej części artykułu problemy ekotoksykologiczne związane z termiczną utylizacją chlorowcopochodnych węglowodorów, każda z powyższych grup odpadów polimerowych może być wykorzystana jako wsad w procesach pirolitycznych. Nie oznacza to jednak, ani tego, że wykorzystywana w każdym przypadku aparatura może być identyczna, ani też tego, że procesy te można prowadzić w identycznym reżimie technologicznym. Również i skład oraz wzajemne proporcje ilościowe pomiędzy poszczególnymi strumieniami produktów poriolitycznych będą się w istotny sposób różnić pomiędzy tymi, a także innymi rzadszymi grupami materiałów [Kardaś, Klein, Kluska, Misiuk 2011].

W krajach słabiej zorganizowanych (np. w Polsce) odpady tworzyw sztucznych sa teoretycznie, przynajmniej wstępnie, selekcjonowane przez mieszkańców, ale i tak wywożone są one wraz z innymi ich rodzajami na wysypiska śmieci i tam ostatecznie selekcjonowane na kilka podstawowych grup: butelki PET, polietylen, polipropylen, plastiki białe, barwione, gumy itp.

Dodatkowo, odpady te są zanieczyszczone resztkami produktów, jakie były w nich sprzedane oraz wszystkim, co może się znaleźć w śmietnikach przydomowych, pojazdach wywożących odpady oraz na wysypiskach. Wymaga to wprowadzenia do poselekcyjnych procesów regranulacji dodatkowego etapu technologicznego jakim jest mycie poddawanych mu detali polimerowych. Osobnym problemem są znajdujące się na opakowaniach naklejki, nadruki oraz inherentnie związana ze współczesnym przemysłem opakowaniowym wielokomponentowa struktura wielowarstwowa opakowań. $W$ realiach współczesnych nawet pozornie cienkie folie opakowań produktów takich jak chipsy i słodycze stanowią kilkuwarstwowy laminat polimerów o różnych własnościach użytkowych (warstwa drukowalna, mechaniczna i barierowa są tu typowymi i w zasadzie zawsze obecnymi przykładami takiej funkcjonalizacji). O ile sam problem opakowań wielowarstwowych przekracza zdecydowanie ramy tego opracowania (i będzie prawdopodobnie przedmiotem osobnego artykułu), to na tym etapie warto jest jedynie zauważyć, że w przypadku opakowań tego typu piroliza jest $\mathrm{w}$ wielu przypadkach technologicznie preferowanym $\mathrm{w}$ stosunku do regranulacji sposobem ich zagospodarowania. Reaktory do pirolizy odpadów tworzyw sztucznych sa 
urządzeniami o zróżnicowanych, często niedopracowanych konstrukcjach i niestety, o dość wysokiej awaryjności. W większości nie mają one systemów dokładnej stabilizacji temperatury i ciśnienia wewnątrz reaktora. A to właśnie te parametry procesu decydują o jakości produktów pirolizy: gazu, oleju i sadzy. Jeśli do tego uwzględnić, że skład wsadu do pieca pirolitycznego jest różny w zależności od źródła odpadów, sposobów ich selekcji oraz stopnia zabrudzenia, łatwo dojść do wniosku, że wytwarzanie dobrej jakości gazu, oleju oraz sadzy jest zadaniem trudnym. Szczególnie kłopotliwe jest otrzymanie sadzy o niskiej zawartości siarki, który to parametr jest uważany z punktu widzenia jej ewentualnego wykorzystania przemysłowego za kluczowy, obok wielkości ziaren i powierzchni właściwej oraz zawartości metali ciężkich.

I tak w przypadku jednego z głównych odbiorców sadzy - przemysłu oponiarskiego zastosowanie sadzy popirolitycznej jest przynajmniej teoretycznie możliwe w procesie produkcji opon do wolnobieżnych pojazdów przemysłowych. Nie jest natomiast dyskutowany jej potencjał aplikacyjny w produkcji opon samochodowych i motocyklowych. Trudne jest również otrzymanie oleju napędowego o niskiej zawartości siarki, odpowiedniej gęstości, oczekiwanie niskich pozostałości po spopieleniu i zawartości wody. Zdecydowanie gorsze, a co więcej mniej powtarzalne pozostają także takie jego parametry funkcjonalne jak temperatura zapłonu, wartość opałowa oraz niska zawartość metali ciężkich [Stelmach 2019]. Prowadzi to do sytuacji, w której podmioty sektora petrochemicznego i tak obciążone problemami technologicznymi, które są skutkiem wymuszanego ustawowo dodatku biokomponentów, nie są zainteresowane ani zakupem paliw popirolitycznych, ani też ich dalszą dystrybucją, zarówno jako osobnych produktów, jak też jako domieszek do paliw otrzymywanych w procesach petrochemicznych. Do dziś w skali światowej utylizacja odpadów komunalnych metodami pirolizy nie weszła do praktyki przemysłowej, mimo nacisku ustawodawców na zmniejszenie emisji $\mathrm{CO}_{2}$ oraz gospodarowania w obiegu zamkniętym. W 2020 r. w Polsce funkcjonowało kilka firm o ustabilizowanej renomie, które wytwarzały sadzę popirolityczną oraz oleje, ale używały one głównie odpadów gumowych jako surowca wsadowego. Większość producentów miała jednak trudności ze sprzedażą wytworzonych sadzy oraz olejów, głównie z przyczyn podanych wyżej. Pod względem zawartości siarki, wielkości ziaren i powierzchni właściwej oraz zawartości metali ciężkich sadze te różniły się znacznie. Stanowiło to o ich zdecydowanie, w porównaniu z komercyjnie dostępnymi sadzami petrochemicznymi, gorszej jakości i ograniczonym zastosowaniu przemysłowym.

Osobną i wykraczająca poza obszar niniejszego opracowania kwestią jest możliwość rozszerzenia funkcjonalności procesów pirolitycznych jaką daje ich połączenie z lokalnymi systemami kogeneracji i trigeneracji energii elektrycznej. O rosnącym, choć powoli, znaczeniu pirolizy jako metody recyklingu odpadów może jednak także świadczyć zakupienie przez koncern Shell (znanego producenta paliw) firmy Nexus Fuel wraz z jej nowatorskimi przemysłowymi instalacjami do pirolizy odpadów [Poszwa 2020]. 


\section{Toksykologiczne aspekty termicznego przekształcania odpadów}

Przeciwnicy spalania, czy szerzej rzecz biorąc energetycznego recyklingu odpadów komunalnych podnoszą niewatpliwie słusznie problemy, jakie związane są z potencjalnie towarzyszaca takim procesom emisja niebezpiecznych dla środowiska naturalnego i zdrowia człowieka związków chemicznych. Do dwóch podstawowych kategorii tych związków zaliczyć możemy metale ciężkie, wraz z ich organicznymi połączeniami chemicznymi oraz halogenowane związki organiczne. Jeśli chodzi o pierwszą z tych grup toksyn to jednym z ich możliwych źródeł sa przypadkowe (bo produkty te powinny trafiać do osobnych strumieni odpadów) i przynajmniej teoretycznie łatwe do uniknięcia zanieczyszczenia strumienia odpadów przedmiotami takimi jak miniaturowe akumulatory ołowiowe i niklowo-kadmowe, baterie srebrowo-rtęciowe, lub też zawierające pewną ilość rtęci starego typu baterie alkaliczne, czy też termometry rtęciowe. Warto nadmienić, że każda z wymienionych tu grup produktów nie jest obecnie dopuszczona na szeroki rynek konsumencki, co nie oznacza jednak jej całkowitej nieobecności w użytkowanym, a przynajmniej gromadzonym w gospodarstwach domowych sprzęcie starszej generacji. Drugim i zdecydowanie trudniejszym do uniknięcia źródłem metali ciężkich są takie wyroby jak obecne na różnego rodzaju przedmiotach farby i lakiery starszej generacji (rtęć i ołów), czy też drobne elementy metalowe zabezpieczane kadmowymi powłokami antykorozyjnymi.

Kolejnym typem odpadów niosących ze sobą zanieczyszczenia metalami ciężkimi są opakowania. Obowiązująca obecnie ustawa z dnia 13 czerwca 2013 r. o gospodarce opakowaniami i odpadami opakowaniowymi (uogoioo) dokonująca wdrożenia przepisów zawartych w dyrektywie 94 /62/WE Parlamentu Europejskiego i Rady z dnia 20 grudnia 1994 r. w sprawie opakowań i odpadów opakowaniowych (Dz.Urz. WE L 365 z 31.12.1994, s. 10, z późn. zm.) oraz dyrektywie Parlamentu Europejskiego i Rady 2009/128/WE z dnia 21 października 2009 r. ustanawiającej ramy wspólnotowego działania na rzecz zrównoważonego stosowania pestycydów (Dz.Urz. UE L 309 z 24.11.2009, s. 71) nie zmienia w zasadzie w tej mierze przepisów wcześniejszych ograniczających zawartość metali ciężkich (rozumianych łącznie jako rtęć, ołów, kadm i chrom VI - z których ten ostatni z powodu swoich odmiennych właściwości chemicznych nie ma w przedmiotowej kwestii żadnego znaczenia) do $100 \mathrm{mg} / \mathrm{kg}$ materiału opakowaniowego. Podobne w nowych regulacjach pozostaja także i dopuszczone osobnym rozporządzeniem (Rozporządzenie Ministra Środowiska z dnia 21 stycznia 2015 r. w sprawie opakowań, do których nie stosuje się wymagań dotyczących zawartości ołowiu, kadmu, rtęci i chromu sześciowartościowego w opakowaniach Dz.U. 2015 poz.137) wyjątki od tej reguły. $\mathrm{Z}$ interesujących nas, a więc potencjalnie podlegających termicznemu przekształceniu polimerowych odpadów opakowaniowych dopuszczalne prawem podwyższone poziomy zawartości metali ciężkich dotyczyć moga jedynie skrzyń i palet z tworzyw sztucznych. Produkty takie muszą być jednak odpowiednio oznakowane, użytkowane w systemie kontrolowanego, ponownego wykorzystania i dystrybucji, a oczekiwany wobec nich poziom zwrotności powinien przekraczać 90\%. Oznacza to w praktyce z jednej strony, że prawdopodobieństwo przedostania się takich odpadów do strumienia komunalnego jest 
nikłe, a z drugiej, że mogą być w nim obecne odpady o wciąż relatywnie wysokiej i niebezpiecznej, bo dochodzącej do $100 \mathrm{mg} / \mathrm{kg}$ zawartości metali ciężkich. W procesach przeróbki termicznej metale te mogą przyjmować formę zarówno połączeń nieorganicznych, co zazwyczaj ma miejsce w atmosferze utleniającej, jak też i organicznych powstających w procesach zachodzących przy ograniczonej dostępności powietrza. Połączenia nieorganiczne to najczęściej stałe składniki pyłów i popiołów, co odróżnia je od obdarzonych i większą lotnościa, i większa, a zarazem zupełnie inaczej ukierunkowaną toksycznością połączeń metaloorganicznych.

I tak przykładowo dla najlepiej poznanych pod względem neurotoksyczności organicznych związków rtęci ich dopuszczalne stężenie średnioroczne w powietrzu atmosferycznym wynosi $0,03 \mathrm{mg} / \mathrm{m}^{3}$, co stanowi dwudziestokrotność średniego stężenia naturalnego wahającego się w granicach $1-2 \mathrm{ng} / \mathrm{m}^{3}$. Zakładając maksymalne dopuszczalne stężenie tego pierwiastka w odpadzie wynoszace $100 \mathrm{mg} / \mathrm{kg}$ możemy bez problemu stwierdzić, że niekontrolowane spalenie $1 \mathrm{~kg}$ takiego odpadu wprowadza w najmniej korzystnej sytuacji do środowiska taką ilość rtęci, jaka jest w stanie zanieczyścić około $3300 \mathrm{~m}^{3}$ powietrza. Dla podkreślenia wagi problemu należy tu przypomnieć, że to właśnie organiczne połączenia rtęci odpowiedzialne były za wybuch w latach 50. XX w. tzw. choroby Minamata [Blenkharn, Hightower 2019]. Jej nazwa pochodzi od japońskiej miejscowości, której mieszkańcy doznali wskutek zatrucia metylortęcią poważnych (na 2256 rozpoznane przypadki 1784 zakończyło się śmiercia) uszkodzeń układu nerwowego.

Równie niebezpieczna, a zarazem dużo powszechniejsza grupa związków toksycznych to halogenowane związki cykliczne z grup dibezno-p-dioksyn, dibenzofuranów i bifenyli określane łącznie jako związki dioksynopodobne. O ile dwie pierwsze podgrupy powstaja praktycznie jedynie $\mathrm{w}$ trakcie procesów spalania zawierających atomy fluorowców związków organicznych to trzecia z nich jest także, choć coraz rzadziej, bo związki te zostały już wycofane z użycia obecna w różnorakich wyrobach przemysłowych, gdzie była od połowy XX w. do mniej więcej 2010 r. szeroko stosowana jako ciekłe i niepalne izolatory w transformatorach i kondensatorach, a także jako smary i plastyfikatory. Głównym i najniebezpieczniejszym jednak źródłem tej grupy toksyn pozostaje jednak spalanie zawierających w swoim składzie atomy chloru tworzyw sztucznych takich jako poli(chlorek winylu) (PCW, PVC). Warto tu zwrócić uwagę na fakt, że o ile w powszechnej świadomości powstawanie toksycznych związków dioksynopodobnych jest związane obecnością w nich organicznie związanego chloru [Łyczko 2017], to istnieją także ich fluorowe [Hagenmaie, Hagenmaier, Schmitz, Schrenk, Weber 1995], bromowe [Environmental Protection Agency 1987] i mieszane [Hagenmaier, Weber 1997] analogi o podobnej, a zarazem mniej zdefiniowanej toksyczności.

W opracowaniach tego tematu podkreśla się zarówno problem środowiskowej trwałości dioksyn, jak też i zdolność do kumulacji w organizmie człowieka i związaną z nią przewlekłą toksyczność i kancerogenność. Przywołany już wcześniej Łyczko zauważa także, że Polska jest jednym z głównych emitentów dioksyn w Unii Europejskiej, co wynika nie tyle z emisji przemysłowych, co z powszechności niezgodnych z prawem praktyk, jakimi są spalanie w paleniskach domowych odpadów tworzyw sztucznych i lakierowanego drewna, czy też 
spalanie odpadów komunalnych na otwartej przestrzeni. Podkreśla się także i to, że kwestia ta dotyczy w zasadzie wyłącznie procesów spalania prowadzonych poza dedykowanymi do tego instalacjami, z których to z powodu niedostatku zastosowanych środków ochronnych nawet przy relatywnie niewielkim wolumenie spalanych materiałów dochodzi do emisji wielokrotnie przekraczających te, których źródłem są wyposażone w specjalistyczne instalacje oczyszczania spalin profesjonalne spalarnie odpadów. Dokonując jednak bardziej szczegółowej analizy porównawczej można zauważyć, że w polskich realiach (dane pochodzą z 2014 r.) pozaprzemysłowe procesy spalania odpowiadają za około 58\% całkowitej emisji dioksyn [Krajowy Ośrodek Bilansowania i Zarządzania Emisjami 2016]. Z kolei według danych dotyczących krajów Wspólnot Europejskich (lata 1995-1997) to profesjonalne spalarnie odpadów komunalnych są największym emitentem dioksyn (25\%), podczas gdy nielegalne spalanie odpadów odpowiada za jedynie 3\% całkowitej emisji [Bröker, Fermann, Quass 2005]. Uwzględniając jednak w tym zestawieniu procesy takie jak spalanie drewna $(16,5 \%)$ czy spalanie odpadów medycznych (14\%) uzyskujemy całkowity udział pozaprzemysłowej emisji dioksyn zbliżony do tego jaki kilkanaście lat później charakteryzował sytuację w Polsce. Zainteresowanych bardziej szczegółowym opisem problemu czytelników moga zainteresować takie pozycje jak dostępne on-line rozdziały w monografiach naukowych [Tarekegn, Akele 2018] czy też podręczniki akademickie [Gaja, Kuropka 2016]. Przykładem pojawiającej się w publicznym dyskursie kontrowersji dotyczącej możliwości termicznego przekształcania odpadów z tworzyw sztucznych zawierających chlorowce może być kilka w zasadzie przeczących sobie na wzajem publikacji dotyczących poli(chlorku winylu). I tak przykładowo M. Ciszewski zwraca uwagę na prowadzoną przez Greenpeace światową kampanię mającą na celu zaprzestanie produkcji i wykorzystania tego tworzywa sztucznego [Ciszewski 2009]. Zwraca się tu uwagę zarówno na obecność w tym materiale stanowiącego jego integralny składnik chloru, ale także i na zawierające brom dodatki uniepalniające, jak też i na potencjalna, choć coraz rzadsza, jako że dodatki funkcjonalne je wykorzystujące są już obecnie wycofane, obecność metali ciężkich. Z kolei autorzy powiązani z sektorem producentów tworzyw sztucznych wydają się w znacznym stopniu pomniejszać problemy związane $\mathrm{z}$ termiczną utylizacją tego tworzywa posuwając się w swoim opracowaniu do dość ryzykownych stwierdzeń negujących nie tyle nawet szkodliwość - bo ta może być wyeliminowana za pomocą odpowiednich systemów filtracji - co uciążliwość technologiczną powstającego przy spalaniu tego tworzywa chlorowodoru. Związek ten, pomijając jego właściwości toksyczne i żrące, jest jednym z silniejszych czynników korozyjnych jakie moga wystapić w instalacjach przemysłowych atakujacym nie tylko typowe stale konstrukcyjne, ale także i stopowe stale kwasoodporne, co oznacza konieczność zastosowania specjalistycznych i przez to znacznie droższych materiałów konstrukcyjnych. Z kolei prezentujący wyważone w tej mierze poglady, Olszowiec, z jednej strony zauważa zagrożenia związane z obecnością w strumieniu spalanych odpadów poli(chlorku winylu), z drugiej jednak strony przedstawia propozycję takiego dostosowania warunków tego procesu (zachowanie nadmiaru powietrza, temperatura spalania powyżej $1100^{\circ} \mathrm{C}$, czas prowadzenia procesu dłuższy niż 2 sekundy, szybkie schładzanie spalin), które w połączeniu z wymaganymi przez prawo 
systemami filtracji spalin oraz zastosowaniem odpowiednich materiałów konstrukcyjnych w krytycznych miejscach instalacji wydają się wystarczającym zabezpieczeniem potrzebnym do zapewnienia bezawaryjności procesu technologicznego, jak i bezpieczeństwa środowiska naturalnego [Olszowiec 2014]. Przedstawione tu - celowo dobrane jako skrajnie różne - dotyczacce tej samej kwestii opinie mogą stanowić przykład tego, jak nieobiektywne dane mogą stanowić argumenty w dyskusji społecznej dotyczącej kwestii termicznego przekształcania odpadów.

\section{Technologie bezpieczne dla środowiska - przykłady}

Warto tu jednak wspomnieć, że wraz z wprowadzeniem coraz to ostrzejszych norm dotyczacych wpływu takich instalacji na środowisko, do ich schematu technologicznego wprowadzane sa, czy to skrubery pozwalające na odsiarczanie i odazotowanie spalin, czy to sorbery zdolne do pochłaniania lotnych form metali ciężkich i związków organicznych. Na przykładzie zdolnej do termicznego przekształcenia 250 tysięcy ton odpadów zmieszanych w skali roku, zrealizowanej w okolicach Tallinna przez estoński koncern energetyczny Eesti Energia elektrociepłowni o rocznej produkcji energii 134 GWhe i 310 GWht, można prześledzić rozwiązania zapewniające jej znikomą uciążliwość środowiskowa. I tak np., komora gromadzenia odpadów znajduje się nie tylko w szczelnej hali, ale zarówno w samej komorze, jak i w całej hali wytwarzane jest w sposób sztuczny podciśnienie, co zapobiega wydostawaniu się na zewnatrz tak pochodzacych z procesu rozdrabniania odpadów pyłów, jak i towarzyszacych im zapachów. Odessane powietrze kierowane jest do palenisk pieców, co zapewnia pełne termiczne przetworzenie zawartych w nim zanieczyszczeń. Z kolei oczyszczanie gazów odlotowych (spalin) realizowane jest w procesie kilkuetapowym obejmującym m.in. usuwanie pyłów i innych czasstek stałych przez filtry workowe i elektrofiltry oraz usuwanie dioksyn i metali ciężkich za pomocą filtrów węglowych. W konsekwencji tak prowadzonego procesu instalacja zdolna do zaopatrzenia w energię około 50 tys. typowych domów mieszkalnych (równowartość około $70 \mathrm{mln} \mathrm{m}^{3}$ gazu ziemnego) emituje do środowiska porównywalną ilość zanieczyszczeń do tej, jaka pochodzi z palenisk 20 opalanych drewnem domów jednorodzinnych.

Kolejnym przykładem całkowicie zintegrowanej z tkanką miejską instalacji do termicznego przekształcania odpadów jest ulokowana, w zasadzie w centrum miasta, bo dzielnicy Spittelau wiedeńska spalarnia odpadów komunalnych. Pierwsza spalarnia odpadów w tym miejscu została wybudowana w 1971 r. Gdy w 1987 r. zniszczył ja pożar zdecydowano o całkowitym wyburzeniu dotychczas wykorzystywanej instalacji i jej odbudowie w nowocześniejszej formie technicznej i architektonicznej. Kolejne prace modernizacyjne zostały zakończone w 2010 r. W chwili obecnej spalarnia ta przetwarza około 250 tys. ton odpadów komunalnych rocznie, co stanowi około $1 / 3$ całkowitej ich ilości powstającej w aglomeracji wiedeńskiej.

Nominalna moc cieplna instalacji wynosi 400 MW, a moc elektryczna 6 MW. Roczna produkcja energii elektrycznej wynosi z kolei od 40 do 120 tys. MWh, a ilość dostarczanego do miejskiej sieci ogrzewania zdalnego ciepła oceniana jest pomiędzy 470 i 500 tys. MWh, 
co pokrywa zapotrzebowanie mniej więcej 60 tys. gospodarstw domowych. Roczna emisja $\mathrm{CO}_{2}$ wynosi z kolei około 27 tys. ton [Kotschan 2017]. Szczegóły integracji wiedeńskiej spalarni odpadów z funkcjonującym w tym mieście systemem gospodarki odpadowej zostały opisane w artykule przeglądowym autorstwa B. Kłopotka i współpracowników [Kłopotek, Krauze, Pajak, Rogalski 2015]. Z kolei przykładem dedykowanego dla przemysłu przetwórstwa odpadów rozwiązania technologicznego służącego do redukcji emisji środowiskowych $\mathrm{z}$ tego typu instalacji może być oferowana przez luksemburska firmę CPPE technologia Kombisorbon $^{\circledR}$, czyli proces pozwalający na oczyszczenie gazów odlotowych z zawartych w nich metali ciężkich (zwłaszcza rtęci i kadmu) oraz ekotoksycznych związków organicznych zawartych w gazach po-pirolitycznych takich jak dioksyny i furany. Przykładowo proces ten zastosowany do gazów odlotowych zawierających do $10 \mathrm{mg} / \mathrm{m}^{3} \mathrm{rtęci}$ i do $30 \mathrm{mg} / \mathrm{m}^{3}$ sumy dioksyn i furanów pozwala na ich oczyszczenie do poziomu zawartości rtęci poniżej 0,001 mg/m³ (10 tys. razy) i 0,004 mg/m³ wspomnianych ekotoksycznych związków organicznych (7500 razy). Co więcej, proces ten zdolny jest do blokowania emisji rtęci zarówno w postaci par metalu, jak też i w postaci związków jonowych.

Podsumowując powyższą analizę warto jest podkreślić zarówno potencjał ekonomiczny i prośrodowiskowy jaki niesie w sobie właściwa implementacja przemysłowa procesów termicznego przekształcania odpadów, jak i wiążące się z nim często racjonalnie nieuzasadnione obawy społeczne. Nie bagatelizując jednakowoż potencjalnych ryzyk i zagrożeń związanych z TPO warto jest przypomnieć, że bez połączonych działań edukacyjnych, jak też i najwyższej możliwej staranności technologicznej prowadzonych inwestycji będą one stanowiły zarzewie konfliktów w otaczających ich lokalizację społeczeństwach lokalnych. Właśnie także i takim celom edukacyjnym służyć ma nie tylko powyższe opracowanie, ale i kolejne artykuły z cyklu, które zostaną poświęcone m.in. takim problemom jak odpady medyczne, elektroniczne, czy też szklane i polimerowe.

\section{Materiały źródłowe}

Literatura:

Blenkharn I., Hightower J.M., 2019, Diagnosis: mercury, money, politics \& poison, Public Health, s. 519-520.

Bröker G., Fermann M., Quass U., 2005, The European Dioxin Emission Inventory Stage II, s. 124-128, Germany.

Czerwińska J., Wielgosiński G., 2019, Spalarnie odpadów komunalnych w Polsce, Nowa Energia, 4 .

Environmental Protection Agency, 1987, PolyhalogenatedDibenzo-p-Dioxines/Dibenzofurans: Testing and Reporting Requirements: Final Rule. 
Gacki M., Lachowicz M., Moskwik K., 2020, Paliwa i motory wzrostu gospodarczego. Wpływ cen surowców i produkcji energii na Polskę, Raport Instytutu Jagiellońskiego, Warszawa.

Gaja K., Kuropka J. (red.), 2016, Powietrze atmosferyczne. Jakość, zagrożenia, ochrona, Oficyna Wydawnicza Politechniki Wrocławskiej, Wrocław.

Główny Urząd Statystyczny, 2018, Infrastruktura komunalna w 2017 r., GUS, Warszawa.

Hagenmaier A., Hagenmaier H., Schmitz H.J., Schrenk D., Weber R., 1995, Polyfluorinated dibenzodioxins and dibenzofurans-synthesis, analysis, formation and toxicology, Chemosphere, s. 629-639.

Hagenmaier H., Weber R., 1997, Synthesis and analysis of mixed chlorinated-fluorinated dibenzo-p-dioxins and dibenzofurans and assessment of formation and occurrence of the fluorinated and chlorinated-fluorinated dibenzo-p-dioxins and dibenzofurans, Chemosphere, s. 13-28.

Kardaś D., Klein M., Kluska J., Misiuk S., 2011, Przebieg i produkty procesu pirolizy wybranych tworzyw sztucznych w reaktorze ciśnieniowym, Inżynieria i Aparatura Chemiczna, 5, s. 54-55.

Kłoptek B.B., Krauze K., Pająk T., Rogalski W., 2015, Gospodarka odpadami. Jak to się robi w Wiedniu? Sozosfera.pl 2015.

Kotschan M., 2017, The Spittelau incinerator: symbiosis of technology, ecology and art, Plasticsle Mag.

Krajowy Ośrodek Bilansowania i Zarządzania Emisjami, 2016, Krajowy bilans emisji $\mathrm{SO}_{2}, \mathrm{NO}_{x^{\prime}}$ $\mathrm{CO}, \mathrm{NH}_{3}, \mathrm{NMLZO}$, pyłów, metali ciężkich i TZO za lata 2013-2014 w układzie klasyfikacji SNAP i NFR, Raport podstawowy, Warszawa.

Łyczko P., 2017, Substancje z grupy dioksyn - zródła pochodzenia i wpływ na zdrowie, Kraków.

Namiecińska O., Wielgosiński G., 2016, Spalarnie odpadów komunalnych - perspektywa roku 2020, Nowa Energia, 2.

Olszowiec P., 2014, Spalarnie śmieci coraz bezpieczniejsze. PCV: spalać czy...nie spalać? Energia Gigawat, 1-2.

Poszwa P., 2020, Nexus Fuel - piroliza tworzyw sztucznych (odzysk monomerów), ekologiczne. com, 2020.

Rajca P., Zajemska M., 2018, Ocena możliwości wykorzystania paliwa RDF na cele energetyczne, Rynek Energii, 4.

Stelmach S., 2019, Piroliza odpadów jako element gospodarki o obiegu zamkniętym, Wydawnictwo Politechniki Śląskiej, Gliwice.

Tarekegn M.M., Akele E.S., 2018, Dioxin and Furan Emissions and Its Management Practices, Published: October $24^{\text {th }} 2018$, DOI: $10.5772 /$ intechopen.80011 
Wieczorek A., Siekierski M., 2020, Zmiany w systemie gospodarki odpadami komunalnymi-aspekty prawne i ekonomiczne na przykładzie m.st. Warszawy, MAZOWSZE Studia Regionalne, 34, Mazowieckie Biuro Planowania Regionalnego, Warszawa, s. 31-58.

Wieczorek A., Siekierski M., 2021, Gospodarka odpadami. Instalacje i urzadzenia do przetwarzania odpadów, MAZOWSZE Studia Regionalne, 36, Mazowieckie Biuro Planowania Regionalnego, Warszawa, s. 31-44.

Akty prawa UE:

Dyrektywa 94 / 62 / WE Parlamentu Europejskiego i Rady z dnia 20 grudnia 1994 r. w sprawie opakowań i odpadów opakowaniowych (Dz.Urz. WE L 365 z 31.12.1994, s. 10, z późn. zm.).

Dyrektywa 2000/76/WE Parlamentu Europejskiego i Rady z dnia 4 grudnia 2000 r. w sprawie spalania odpadów (opublikowano w Dzienniku Urzędowym Unii Europejskiej 28 grudnia 2000).

Dyrektywa Parlamentu Europejskiego i Rady 2008/98/WE z dnia 19 listopada 2008 r. w sprawie odpadów oraz uchylająca niektóre dyrektywy (Tekst mający znaczenie dla EOG) (opublikowano w Dzienniku Urzędowym Unii Europejskiej 22 listopada 2008).

Dyrektywa Parlamentu Europejskiego i Rady 2009/128/WE z dnia 21 października 2009 r. ustanawiającej ramy wspólnotowego działania na rzecz zrównoważonego stosowania pestycydów (Dz.Urz. UE L 309 z 24.11.2009, s. 71).

Rozporządzenie Parlamentu Europejskiego i Rady (UE) 2019/2088 z dnia 27 listopada 2019 r. $\mathrm{w}$ sprawie ujawniania informacji związanych ze zrównoważonym rozwojem w sektorze usług finansowych (Tekst mający znaczenie dla EOG) (opublikowano w Dzienniku Urzędowym Unii Europejskiej 9 grudnia 2019).

Rozporządzenie Parlamentu Europejskiego i Rady (UE) 2020 / 852 z 18 czerwca 2020 r. w sprawie ustanowienia ram ułatwiających zrównoważone inwestycje, zmieniające rozporządzenie (UE) 2019/2088 (Tekst mający znaczenie dla EOG) (opublikowano w Dzienniku Urzędowym Unii Europejskiej 22 czerwca 2020).

Ustawy:

Ustawa z dnia 7 lipca 1994 r. Prawo budowlane (t.j. z dnia 7 lipca 2020 r. Dz.U. z 2020 r. poz. 1333 z późn. zm.), w skrócie uPb.

Ustawa z dnia 27 marca 2003 r. o planowaniu i zagospodarowaniu przestrzennym (t.j. z dnia 31 marca 2021 r. Dz.U. z 2021 r. poz. 741 z późn. zm.), w skrócie upzp. 
Ustawa z dnia 3 października 2008 r. o udostępnianiu informacji o środowisku i jego ochronie, udziale społeczeństwa w ochronie środowiska oraz o ocenach oddziaływania na środowisko (t.j. z dnia 20 stycznia 2021 r. Dz.U. z 2021 r. poz. 247, z późn. zm.), w skrócie uiś.

Ustawa z dnia 14 grudnia 2012 r. o odpadach (t.j. z dnia 15 kwietnia 2021 r., Dz.U. z 2021 r. poz. 779 z późn. zm.), w skrócie uod.

Ustawa z dnia 13 czerwca 2013 r. o gospodarce opakowaniami i odpadami opakowaniowymi (t.j. z dnia 29 maja 2020 r., Dz.U. z 2020 r. poz. 1114), w skrócie uogoioo.

Rozporządzenia:

Rozporządzenie Ministra Środowiska z dnia 21 stycznia 2015 r. w sprawie opakowań, do których nie stosuje się wymagań dotyczących zawartości ołowiu, kadmu, rtęci i chromu sześciowartościowego w opakowaniach (Dz.U. z 2015 r. poz. 137).

Rozporządzenie Ministra Gospodarki z dnia 16 lipca 2015 r. w sprawie dopuszczania odpadów do składowania na składowiskach (opublikowano w Dzienniku Ustaw 1 września 2015 r. Dz.U. z 2015 r. poz. 1277).

Rozporządzenie Ministra Środowiska z dnia 29 grudnia 2016 r. w sprawie szczegółowego sposobu selektywnego zbierania wybranych frakcji odpadów (t.j. z dnia 7 października 2019 r., Dz.U. z 2019 r. poz. 2028).

Rozporządzenie Rady Ministrów z dnia 10 września 2019 r. w sprawie przedsięwzięć mogących znacząco oddziaływać na środowisko (Dz.U. z 2019 r. poz. 1839).

Rozporządzenie z dnia 2 stycznia 2020 r. Ministra Klimatu w sprawie katalogu odpadów (Dz.U. z 2020 r. poz. 10).

Normy:

EN 15359:2010 Solid recovered fuels - Specifications and classes, Brussels, Belgium: CEN

EN 15591:2007 - Solid recovered fuels - Determination of the biomass content based on the $14 \mathrm{C}$ method, Brussels, Belgium: CEN

EN 15440:2011 - Solid recovered fuels - Methods for the determination of biomass content, Brussels, Belgium: CEN 
Waste management. Thermal waste treatment - incinerators and co-incinerators

\section{ABSTRACT}

Waste management is a series of processes related to the generation, collection and supervision of waste. Waste treatment plays a key role in these processes. Waste management also covers issues related to the service of their disposal sites. Currently, it is one of the most important issues concerning modern civilization due to the growing problem of environmental pollution.

This paper is another in a series of articles on waste management [Siekierski, Wieczorek 2020].

The aim of this article is to provide objective information on thermal treatment of waste, around which a number of myths have arisen concerning both its advantages and its harmfulness to the environment. It is a special method of waste treatment because it can involve both disposal and recovery. Thermal treatment of waste is primarily carried out in incinerators as well as in co-incinerators, which may be, in addition to dedicated installations designed for this purpose (i.e. those whose only object of operation is thermal treatment of waste, e.g. by incineration), also such industrial installations which have already been installed in industrial plants with a completely different profile, e.g. in cement factories, power plants and heat and power stations. One of the next articles in the series will also present methods of waste disposal using plasma technologies, which belong to the same group of thermal processes. An interesting comparison of these three technologies can be found in a paper published in 2018 in the journal Energy Market [Rajca, Zajemska 2018].

It is not the intention of the authors to lobby for any method of thermal waste conversion.

Key words: thermal treatment of waste, incinerators, co-incinerators, waste, waste management, waste disposal 
Maciej Siekierski, dr hab. inż. - absolwent Wydziału Chemicznego Politechniki Warszawskiej, długoletni pracownik naukowy tego wydziału, a od 2013 adiunkt habilitowany. Specjalista w zakresie elektrochemii, chemicznych źródeł prądu i magazynowania oraz konwersji energii. ego zainteresowania badawcze oprócz recyklingu półprzewodników i półprzewodnikowych źródeł światła obejmują także recykling i powtórne wykorzystanie ogniw galwanicznych i inne procesy Gospodarki Obiegu Zamkniętego. Współpracuje z Klastrem Gospodarki Odpadowej i Recyklingu.

Maciej Siekierski, dr hab. inż. (PhD, DEng) - graduate of the Faculty of Chemistry at Warsaw University of Technology, a long-term researcher at this faculty and assistant professor since 2013. Specialist in the field of electrochemistry, chemical energy sources, storage and conversion. His research interests, in addition to the recycling of semiconductors and semiconductor light sources, also include recycling and reuse of galvanic cells and other circular economy processes. He collaborates with the Waste Management and Recycling Cluster.

Karolina Majewska, inż. - absolwentka Wydziału Inżynierii Wyższej Szkoły Inżynierii i Zdrowia w Warszawie i studentka Wydziału Chemicznego Politechniki Warszawskiej. Specjalizuje się w zakresie elektrochemii i chemii nieorganicznej. Jej zainteresowania badawcze obejmuja przede wszystkim nowe materiały wykorzystywane w elektrochemicznych procesach wytwarzania $i$ konwersji energii.

Karolina Majewska, inż. (BEng) - graduate of the Faculty of Engineering at the Warsaw College of Health and Engineering and a student at the Faculty of Chemistry at the Warsaw University of Technology. Specialist in the field of electrochemistry and inorganic chemistry. Her research interests primarily include new materials used in electrochemical energy generation and conversion processes.

Sławomir Podsiadło, prof. dr hab. inż. - absolwent Wydziału Chemicznego Politechniki Warszawskiej, długoletni pracownik naukowy tego wydziału, a od 2011 jego profesor tytularny. Specjalista w obszarze chemii nieorganicznej zwiq̨zów beztlenowych, materiałów półprzewodnikowych wykorzystywanych do konwersji energii i w ogniwach fotowoltaicznych. Jego zainteresowania badawcze obejmujq także recykling półprzewodników i półprzewodnikowych źródeł światła. Konsultant w przemysłowych projektach zwiq̨zanych z pirolizą materiałów polimerowych.

Sławomir Podsiadło, prof. dr hab. inż. (PhD, DEng, Professor) - graduate of the Faculty of Chemistry at Warsaw University of Technology, a long-term researcher at this faculty and its titular Professor since 2011. Specialist in the field of inorganic chemistry of anaerobic compounds, semiconductor materials used for energy conversion and in photovoltaic cells. His research interests also include the recycling of semiconductors and semiconductor light sources. Consultant for industrial projects related to the pyrolysis of polymeric materials. 